INDO GLOBAL JOURNAL OF

PHARMACEUTICAL SCIENCES

ISSN 2249- 1023

\title{
Meiotic Studies of Heteropogon contortus (L.) Beauv. ex. Roem. et Schult
}

\author{
B. Sharma ${ }^{1 *}$, A.K. Srivastava ${ }^{2}$, Neha Mittal ${ }^{1}$ \\ ${ }^{1}$ Institute of Applied Medicines \& Research, Ghaziabad, U.P., India \\ ${ }^{2}$ Department of Chemistry, C.C.S. University, Meerut-250005, U.P., India
}

Address for Correspondence: B. Sharma; sharmababita176@gmail.com

\begin{abstract}
The genus Heteropogon Pers. (systematic position: Poaceae; Panicoideae; Andropogonodae; Andropogoneae; Andropogoninae) has seven species distributed throughout the tropical region. The species grow on dry places, often on poor soils. Several species of the Graminaceous genera, Heteropogon were analyzed cytologically in detail. This article deals with the male meiosis in six collections of $H$. Contortous. The chromosomes configuration observed were univalents, bivalents, trivalents and quadrivalents. In all the collections the frequency of bivalents was much higher than Is, IIIs and IVs. Most of the bivalents were of rod-shaped. Further, the collections were more or less similar in possessing the amount of total meiotic anomalies, meiotic anomalies during first and second meiotic divisions, chiasmata per PMC, pollen fertility, pollen diameter and number of pollen per anther. In addition to microspore tetrads, diads, triads and pentad were reported in both collections. @ 2014 iGlobal Research and Publishing Foundation. All rights reserved.
\end{abstract}

Conference Proceedings: International Conference on Life Sciences, Informatics, Food and Environment; August 29- 30, 2014

Indo Global Journal of Pharmaceutical Sciences( ISSN 22491023 ; CODEN- IGJPAI; NLM ID: 101610675) indexed and abstracted in EMBASE(Elsevier), SCIRUS(Elsevier),CABI, CAB Abstracts, Chemical Abstract Services(CAS), American Chemical Society(ACS), Index Copernicus, EBSCO, DOAJ, Google Scholar and many more. For further details, visit 